\title{
Pengaruh Profitabilitas, Leverage, Kinerja Lingkungan dan Diversifikasi Gender Terhadap Pengungkapan Lingkungan Pada Perusahaan Pertambangan di Indonesia
}

\author{
Amanda Oktariyani ${ }^{1}$, Yuni Rachmawati ${ }^{2}$ \\ ${ }^{1}$ Jurusan Akuntansi, Universitas Tridinanti Palembang \\ Email:amanda oktariyani@univ-tridinanti.ac.id \\ ${ }^{2}$ Jurusan Akuntansi, Universitas Tridinanti Palembang \\ Email:yunirachmawatise@gmail.com
}

\begin{abstract}
This paper investigates the effect of profitability, leverage, environmental performance and gender diversity on the quality of environmental disclosure by analyzing annual report of mining companies listed on Indonesia Stock Exchange during 2017 - 2019. Based on the purposive sampling method, 25 mining companies were selected. This study used panel data regression as the data analysis method. The result showed that profitability, leverage and gender diversity has not significant effect on quality of environmental disclosure, while environmental performance has positive and significant effect on quality of environmental disclosure. Thus, companies that has ISO 14001 certification tend to disclose information related to their responsibility to the environment more detail in annual reports. The results of this study are expected to contribute to the literature review regarding the motivations behind corporate environmental disclosure.
\end{abstract}

Keywords: Profitability, Leverage, Environmental Performance, Gender Diversity Environmental Disclosure.

\begin{abstract}
ABSTRAK
Penelitian ini bertujuan untuk mengetahui pengaruh profitabilitas, leverage, kinerja lingkungan dan keberagaman gender terhadap kualitas pengungkapan lingkungan pada perusahaan pertambangan periode 2017 - 2019. Sampel yang digunakan dalam penelitian ini berjumlah 25 perusahaan. Berdasarkan analisis regresi data panel, hasil penelitian menunjukkan bahwa profitabilitas, leverage dan keberagaman gender tidak memiliki pengaruh terhadap kualitas pengungkapan lingkungan, sementara kinerja lingkungan yang diproksikan dengan sertifikat ISO14001 memiliki pengaruh terhadap kualitas pengungkapan lingkungan. Hasil penelitian ini menunjukkan perusahaan yang memiliki sertifikasi lingkungan ISO 14001 cenderung lebih banyak mengungkapkan informasi mengenai tanggung jawab mereka terhadap lingkungan di dalam laporan tahunannya. Hasil penelitian ini diharapkan dapat memberikan kontribusi terhadap kajian literatur mengenai motivai dibalik pengungkapan lingkungan perusahaan.
\end{abstract}

Kata kunci: Profitabilitas, Leverage, Kinerja Lingkungan, Pengungkapan Lingkungan. 


\section{Pendahuluan}

Aktivitas pertambangan di Indonesia seringkali menimbulkan pro dan kontra. Di satu sisi, kehadiran aktivitas tambang ini dipandang dapat memberikan dampak positif bagi sebagian masyarakat di daerah konsesi karena dengan adanya aktivitas pertambangan tersebut juga turut menciptakan lapangan pekerjaan serta meningkatkan aktivitas perekonomian lokal disana [13]. Namun, di sisi kontra terlihat jauh lebih banyak dampak negatifnya. Kegiatan pertambangan disebut telah menyebabkan kerusakan lingkungan seperti pencemaran air sungai maupun laut yang dapat merusakan hutan mangrove serta biota laut, pencemaran tanah yang membuat tumbuhan di atasnya mati, pencemaran udara yang dapat menyebabkan penyakit bagi manusia serta dapat menyebabkan banjir maupun longsor karena semakin sedikit hutan yang seharusnya menjadi daerah resapan air [4]. Sebagai contoh, sejumlah pertambangan yang dilakukan secara destruktif seperti pengalian tanah yang tidak sesuai menurut hasil penelitian [4] telah merusak kelestarian lingkungan dan menyebabkan pencemaran di Provinsi Aceh. Meskipun demikian, pertambangan pada dasarnya memiliki peran penting bagi manusia karena kebutuhan manusia akan energi juga merupakan hal yang tidak terbantahkan. Kegiatan pertambangan khususnya batubara juga merupakan salah satu pemanfatan sumber daya alam yang merupakan bagian dari pelaksanaan pembangunan nasional yang pada hakikatnya ditujukan untuk meningkatkan kesejahteraan masyarakat [20]. Dalam hal ini, aktivitas penambangan harus dilakukan sesuai dengan Undang-Undang yang ada dan harus memperhatikan lingkungan sekitar.

Dalam kajian akuntansi, tanggung jawab perusahaan sosial dan lingkungan ini lebih sering disebut dengan istilah Corporate Social Responsibility (CSR). Berdasarkan literatur-literatur tentang CSR ini, perusahaan dikatakan harus mampu menunjukkan tanggung jawabnya terhadap lingkungan dan sosial demi keberlangsungan perusahaan itu sendiri, dimana hal ini sesuai dengan teori legitimasi. Selain itu, perusahaan juga harus mampu memenuhi informasi yang diperlukan oleh para stakeholder karena menurut Teori Stakeholder dengan menyeimbangkan kepentingan seluruh stakeholder maka dapat memaksimalkan kinerja berkelanjutan dan nilai jangka panjang perusahaan [25]. Berdasarkan teori-teori tersebut, penelitian mengenai motivasi pengungkapan informasi lingkungan semakin banyak dilakukan seperti [1] yang meneliti mengenai pengaruh tipe industri, profitabilitas dan leverage terhadap pengungkapan lingkungan pada perusahaan di Iran. Perbedaan penelitian ini dengan penelitian sebelumnya yaitu penelitian ini akan menguji pengaruh variabel profitabilitas dan leverage terhadap kualitas pengungkapan informasi lingkungan pada perusahaan pertambangan di Indonesia, sedangkan penelitian terdahulu lebih banyak mengukur kuantitas pengungkapan saja. Perbedaan lainnya yaitu penelitian ini menambahkan variabel kinerja lingkungan yang diproksikan dengan keberhasilan perusahaan dalam memperoleh sertifikat ISO 14001 tentang sistem manajemen lingkungan. Selain itu, penelitian ini juga menambahkan variabel gender karena berdasarkan penelitian [9] dijelaskan bahwa keberagaman gender dalam jajaran direksi di perusahaan memiliki pengaruh terhadap pelaporan keberlanjutan lingkungan dan hasil tersebut menunjukkan bahwa dengan kehadiran wanita dalam jajaran direksi memberikan berbagai keterampilan, pengalaman dan 
https://akuntansi.pnp.ac.id/jam

merupakan sumber daya yang unggul sehingga membuat kemajuan atau peningkatan dalam pelaporan lingkungan. Berdasarkan latar belakang tersebut, maka penelitian ini akan membuktikan apakah profitabilitas, leverage, kinerja lingkungan dan gender memiliki pengaruh terhadap kualitas pengungkapan lingkungan pada perusahaan pertambangan di Indonesia.

\section{Tinjauan Pustaka}

\section{Teori Legitimasi}

Teori legitimasi menjelaskan bahwa organisasi secara terus-menerus akan beroperasi sesuai batas-batas dan nilai perusahaan. Teori ini juga menganjurkan perusahaan untuk meyakinkan bahwa aktivitas dan kinerjanya dapat diterima masyarakat. Dalam hal ini, perusahaan menggunakan laporan tahunan mereka untuk menggambarkan kesan tangung jawab lingkungan sehingga mereka dapat diterima oleh masyarakat [7].

Ulum menjelaskan bahwa menurut pandangan teori legitimacy, perusahaan akan terdorong untuk menunjukkan kapasitas intellectual capital (IC-nya) dalam laporan keuangan untuk memperoleh legitimasi dari publik atas kekayaan intelektual yang dimilikinya [28]. Pengakuan legitimasi publik ini menjadi penting bagi perusahaan untuk mempertahankan eksistensinya. Berdasarkan teori ini, variabel pengungkapan lingkungan menjadi hal yang dilakukan sebagai upaya memperoleh legitimasi publik supaya keberlangsungan perusahaan dapat terjaga. Sejalan dengan hal tersebut, [10] menyebutkan Teori Legitimasi menjelaskan bahwa perusahaan terikat kontrak sosial dengan masyarakat dimana perusahaan tersebut beroperasi. Kegagalan pemenuhan kontrak sosial tersebut dapat mengancam kinerja dan keberlangsungan perusahaan. Oleh sebab itu, perusahaan dengan tingkat profitabilitas yang lebih tinggi dengan kemampuan yang dimiliki sudah seharusnya dapat membuat pengungkapan informasi sosial dan lingkungan yang lebih baik dibandingkan perusahaan non-profitable. Dengan kata lain, [19] menyebutkan bahwa perusahaan dengan tingkat profitabilitas yang lebih tinggi memiliki insentif untuk membedakan dirinya dengan perusahaan yang less profitable melalui pengungkapan sosial dan pengungkapan informasi lingkungan. Demikian halnya dengan tingkat leverage. Perusahaan dengan tingkat leverage yang lebih tinggi berada dalam kondisi yang beresiko sehingga mereka memerlukan upaya menjaga legitimasinya. Dalam hal ini, perusahaan dengan tingkat leverage yang lebih tinggi akan membuat pengungkapan informasi sosial dan lingkungan yang lebih banyak sebagai upaya menjaga keberlangsungan perusahaannya di dalam masyarakat.

\section{Teori Keagenan}

Teori keagenan (Agency Theory) menurut Jensen \& Meckling dalam [14] adalah teori yang menjelaskan adanya suatu kontrak antara dua pihak yang memuat pendelegasian pekerjaan dan wewenang oleh pihak pertama (sebagai principal) kepada pihak kedua (sebagai agent) agar pihak kedua bersedia melakukan pekerjaan tersebut untuk kepentingan pihak pertama. Dua masalah yang sering timbul akibat kontrak yaitu masalah keagenan dan masalah risk sharing. Masalah keagenan adalah masalah yang muncul akibat perbedaan tujuan antara principal dan agent, sedangkan masalah risk sharing muncul karena perbedaan preferensi resiko antara principal dan agent. 
Hubungan keberagaman gender dengan pengungkapan informasi lingkungan didasari oleh teori keagenan ini. Farida menyebutkan bahwa menurut Teori Keagenan ini, keberadaan dewan direksi wanita akan meningkatkan independensi dewan direksi sehingga akan mengurangi biaya agensi dan sebagai konsekuensinya akan terjadi peningkatan nilai perusahaan [15]. Terkait dengan pelaporan sukarela, termasuk pelaporan mengenai informasi lingkungan, menurut teori keagenan pengungkapan ini dimaksudkan untuk meningkatkan pengawasan terhadap pihak manajemen. Perusahaan yang dengan sukarela membuat laporan tangung jawab sosial dan lingkungan dalam laporan tahunannya dianggap lebih bertangung jawab terhadap keadaan sosial dan lingkungan. Hal ini dapat meningkatkan hubungan antara perusahaan dengan para pemangku kepentingan sehingga pada akhirnya juga dapat mengurangi masalah keagenan. Sejalan dengan teori tersebut, penelitian [17] membuktikan bahwa keberagaman gender berpengaruh terhadap pengungkapan tangung jawab sosial dan lingkungan dan disebutkan bahwa keberadaan perempuan dalam jajaran direksi sangat berkaitan dengan tangung jawab perusahaan yang baik dan mematuhi norma serta nilai sosial.

\section{Teori Stakeholder}

Teori Stakeholder adalah teori yang menjelaskan bahwa setiap stakeholder memiliki hak untuk disediakan informasi tentang bagaimana bagaimana aktivitas perusahaan dapat memengaruhi mereka. Lebih lanjut [10] dalam [28] menjelaskan bahwa teori ini menyatakan jika organisasi akan memilih secara sukarela mengungkapkan informasi tentang kinerja lingkungan, sosial dan intelektual mereka, melebihi dan di atas permintaan wajibnya, untuk memenuhi eskpektasi sesungguhnya atau yang diakui oleh stakeholder. Para stakeholder akan memberikan dukungan penuh kepada aktivitas perusahaan apabila pengungkapan tanggung jawab sosial dan lingkungan tersebut dapat dilakukan dengan baik, sehingga tujuan perusahaan untuk meningkatkan kinerja dan laba dapat tercapai [30]. Berdasarkan teori ini, pengungkapan informasi terkait informasi keuangan, sosial dan kinerja lingkungan menjadi faktor yang diduga dapat menentukan luasnya pengungkapan informasi lingkungan atau dalam penelitian ini diukur dengan kualitas pengungkapan lingkungan. Sejalan dengan teori ini, perusahaan akan berusaha mengungkapkan informasi yang diharapkan oleh para pemegang kepentingan. Informasi yang dimaksud dalam hal ini adalah informasi terkait keuangan, sosial maupun lingkungan dengan tujuan memenuhi harapan kelompok pemegang kepentingan.

\section{Pengungkapan Lingkungan}

Pengungkapan lingkungan adalah pengungkapan yang berkaitan dengan dampak yang ditimbulkan dari suatu proses atau operasi perusahaan terhadap lingkungan [8] Dengan kata lain, pengungkapan informasi lingkungan ini secara umum dapat didefinisikan sebagai media sarana perusahaan untuk menginformasikan tentang kegiatan kinerja lingkungan perusahaan. Utomo selanjutnya menyebutkan bahwa pelaporan tanggung jawab sosial dan lingkungan untuk Perseroan Terbatas di Indonesia bersifat wajib dimana hal tersebut tertuang dalam undang-Undang No. 40 Tahun 2007 ayat 66 (2c), namun demikian belum ada 
pedoman baku yang mengatur tentang seberapa luas banyaknya item-item yang harus diungkap [29].

\section{Kerangka Pemikiran}

\section{Gambar 1. Kerangka Pemikiran}

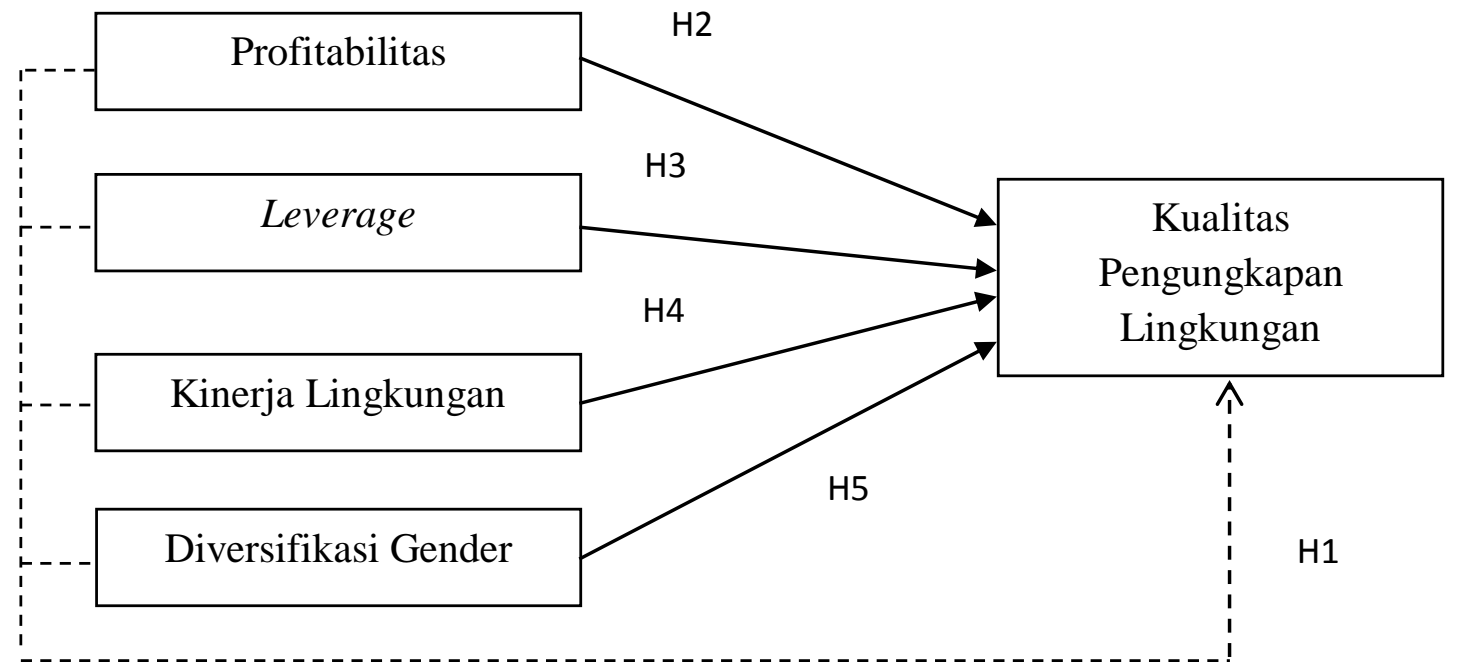

\section{Pengembangan Hipotesis}

H1 : Profitabilitas, leverage, kinerja lingkungan dan diversifikasi gender berpengaruh terhadap kualitas pengungkapan lingkungan pada perusahaan pertambangan yang terdaftar di BEI periode 2017-2019.

H2 : Profitabilitas berpengaruh terhadap kualitas pengungkapan lingkungan pada perusahaan pertambangan yang terdaftar di BEI periode 2017-2019.

H3 : Leverage berpengaruh terhadap kualitas pengungkapan lingkungan pada perusahaan pertambangan yang terdaftar di BEI periode 2017-2019.

H4 : Kinerja lingkungan berpengaruh terhadap kualitas pengungkapan lingkungan pada perusahaan pertambangan yang terdaftar di BEI periode 2017-2019.

H5 : Diversifikasi Gender berpengaruh terhadap kualitas pengungkapan lingkungan pada perusahaan pertambangan yang terdaftar di BEI periode 2017-2019.

\section{METODE PENELITIAN}

\section{Sampel Penelitian}

Sampel yang digunakan dalam penelitian ini berjumlah 25 perusahaan seperti yang disebutkan dalam Lampiran. Jumlah sampel diperoleh dari teknik purposive sampling dengan kriteria sebagai berikut:

- Perusahaan terdaftar di Bursa Efek Indonesia Periode 2017-2019 dan tidak delisiting selama periode tersebut.

- Perusahaan mempublikasikan Laporan Tahunan selama periode 2017 - 2019. 
Tabel 1. Daftar Sampel Penelitian

\begin{tabular}{|c|c|l|}
\hline No & Kode & \multicolumn{1}{|c|}{ Nama Perusahaan } \\
\hline 1 & ADRO & Adaro Energy Tbk \\
\hline 2 & BRMS & Bumi Resources Minerals Tbk \\
\hline 3 & DEWA & Darma Henwa Tbk \\
\hline 4 & DOID & Delta Dunia Makmur Tbk \\
\hline 5 & GEMS & Golden Energy Mines Tbk \\
\hline 6 & GTBO & Garda Tujuh Buana Tbk \\
\hline 7 & HRUM & Harum Energy Tbk \\
\hline 8 & ITMG & Indo Tambangraya Megah Tbk \\
\hline 9 & KKGI & Resource Alam Indonesia Tbk \\
\hline 10 & MBAP & Mitra Bara Adiperdana Tbk \\
\hline 11 & MYOH & Samindo Resources Tbk \\
\hline 12 & PTRO & Petrosea Tbk \\
\hline 13 & SMMT & Golden Eagle Energy Tbk \\
\hline 14 & TOBA & TBS Energi Utama Tbk \\
\hline 15 & ARTI & Ratu Prabu Energi Tbk \\
\hline 16 & BIPI & Benakat Petroleum Energy Tbk \\
\hline 17 & ELSA & Elnusa Tbk \\
\hline 18 & ENRG & Energi Meda Persada Tbk \\
\hline 19 & ESSA & Surya Esa Perkasa Tbk \\
\hline 20 & MEDC & Medco Energy International Tbk \\
\hline 21 & RUIS & Radiant Utama Interinsco Tbk \\
\hline 22 & CKRA & Cakra Mineral Tbk \\
\hline 23 & INCO & Vale Indonesia \\
\hline 24 & MDKA & Merdeka Copper Gold Tbk \\
\hline 25 & PSAB & J Resources Asia Pasifik Tbk \\
\hline & & \\
\hline 19 & \\
\hline 19 &
\end{tabular}

\section{Definisi Operasional Variabel}

\section{Variabel Dependen}

Dalam penelitian ini, kualitas pengungkapan lingkungan diuji melalui analisis konten. Dengan teknik ini, pengungkapan lingkungan dianalisis berdasarkan Environmental Disclosure Items yang diadaptasi dari penelitian [27] dengan kategori (tema) pengungkapan lingkungan yang terdiri dari pengurangan polusi atau pengendalian pencemaran lingkungan, pelaporan pengembangan berkelanjutan, manajemen lingkungan, perikatan stakeholder, informasi negatif dan informasi yang berkaitan dengan hukum, remediasi dan kontaminasi lahan serta pengungkapan terkait lingkungan lainnya. Penilaian pengungkapan tersebut menggunakan skor seperti yang digunakan dalam penelitian [12] yaitu skor "0" jika kategori tidak 
diungkapkan, skor "1" jika diungkapkan secara umum, skor "2" jika diungkapkan secara spesifik dan skor "3" jika diungkapkan secara kuantitatif atau dalam satuan moneter.

Sementara untuk menilai kualitas pengungkapan lingkungannya diperoleh dari perhitungan seperti berikut:

$$
Q E D=\frac{\Sigma \mathrm{X}}{\mathrm{N}}
$$

Keterangan :

KPL $=$ Kualitas Pengungkapan Lingkungan

$\Sigma \mathrm{X}=$ Total skor pengungkapan lingkungan perusahaan

$\mathrm{N}=$ Jumlah kategori pengungkapan lingkungan

\section{Variabel Independen}

\section{Profitabilitas}

Profitabilitas merupakan kemampuan perusahaan untuk memperoleh laba dari kegiatan bisnis yang dilakukan [22]. Rasio profitabilitas dalam penelitian ini diproksikan dengan Return on Asset (ROA) karena nilai ROA dapat dijadikan tolak ukur yang berharga untuk membandingkan kemampuan perusahaan untuk menghasilkan laba. Return on Asset diperoleh dengan membagi laba bersih dengan total aset.

$$
\text { Return on Asset }=\frac{\text { Laba Bersih }}{\text { Total Aset }}
$$

\section{Leverage}

Leverage dalam penelitian ini diproksikan dengan Debt to Equity Ratio (DER) sebab nilai $D E R$ dapat menunjukkan kelayakan keuangan jangka panjang dan tingkat risiko bisnis. Debt to Equity Ratio yang diukur dengan membagi total hutang dengan total ekuitas perusahaan.

$$
\text { Debt to Equity Ratio }=\frac{\text { Total Hutang }}{\text { Total Ekuitas }}
$$

\section{Kinerja Lingkungan}

Variabel kinerja lingkungan dalam penelitian ini merupakan variabel dummy yang diproksikan dengan perolehan sertifikat IS014001. ISO 14001 merupakan standar internasional untuk manajemen sistem lingkungan yang memungkinkan organisasi mengembangkan dan menerapkan kebijakan dan tujuantujuan yang berkaitan dengan sistem manajemen lingkungan (ISO 14001, 2015). Dalam penelitian ini, perusahaan akan diberikan nilai 1 (satu) jika perusahaan memperoleh sertifikat ISO 14001 dan nilai 0 (nol) jika tidak memperoleh sertifikat 14001. Dalam penilaian sertifikasi ISO 14001, biasanya masa berlakunya adalah 3 
https://akuntansi.pnp.ac.id/jam

tahun sehingga data yang diperoleh dalam jangka waktu penelitian ini bisa sama nilainya selama 3 tahun berturut-turut.

\section{Diversifikasi Gender}

Diversifikasi Gender dalam penelitian ini juga menggunakan variabel dummy dimana jika terdapat wanita dalam jajaran dewan direksi dan/atau dewan komisaris atau dewan direksi, maka akan diberi nilai 1 (satu). Sebaliknya, jika tidak ada wanita dalam jajaran tersebut maka akan diberi nilai nol (0).

\section{HASIL PENELITIAN DAN PEMBAHASAN}

\section{Statistik Deskriptif}

Penelitian ini menggunakan variabel dependen berupa kualitas pengungkapan lingkungan perusahaan serta empat variabel independen yaitu profitabilitas, leverage, kinerja lingkungan serta gender. Berikut deskripsi dari masing-masing variabel penelitian:

Tabel 2. Statistik Deskriptif

\begin{tabular}{|l|c|c|c|c|c|}
\hline & $\mathrm{Y}$ & $\mathrm{X} 1$ & $\mathrm{X} 2$ & $\mathrm{X} 3$ & $\mathrm{X} 4$ \\
\hline Mean & 0.452000 & 5.248933 & 11.63133 & 0.466667 & 0.373333 \\
\hline Median & 0.440000 & 2.600000 & 1.800000 & 0.000000 & 0.000000 \\
\hline Maximum & 0.930000 & 55.00000 & 123.0000 & 1.000000 & 1.000000 \\
\hline Minimum & 0.040000 & -7.290000 & 0.000000 & 0.000000 & 0.000000 \\
\hline Std. Dev. & 0.261369 & 9.132807 & 21.43308 & 0.502247 & 0.486947 \\
\hline Skewness & 0.388451 & 3.072166 & 2.636819 & 0.133631 & 0.523752 \\
\hline Kurtosis & 2.128909 & 14.96571 & 11.61441 & 1.017857 & 1.274316 \\
\hline & & & & & \\
\hline Jarque-Bera & 4.257422 & 565.4094 & 318.8102 & 12.50100 & 12.73515 \\
\hline Probability & 0.118991 & 0.000000 & 0.000000 & 0.001929 & 0.001716 \\
\hline & & & & & \\
\hline Sum & 33.90000 & 393.6700 & 872.3500 & 35.00000 & 28.00000 \\
\hline Sum Sq. Dev. & 5.055200 & 6172.204 & 33993.90 & 18.66667 & 17.54667 \\
\hline \multicolumn{2}{|c|}{} & 75 & & & 75 \\
\hline Observations & 75 & 75 & 75 & \\
\hline
\end{tabular}

Variabel Y dalam penelitian ini merupakan kualitas pengungkapan lingkungan perusahaan. Berdasarkan tabel di atas, rata-rata untuk variabel Y ini adalah 0,4520 atau 45\%. Hal ini berarti bahwa dalam satu periode laporan tahunan, perusahaan rata-rata telah mengungkapkan $45 \%$ dari tema pengungkapan lingkungan sebagai bentuk dari tangung jawab perusahaan terhadap lingkungan. Indeks pengungkapan terkecil yaitu 0,0400 atau hanya sebesar $4 \%$ dan indeks pengungkapan terbesar yaitu 0,930 atau sebesar $93 \%$.

Variabel X1 yaitu profitabilitas yang diproksikan dengan Return on Asset (ROA) menunjukkan nilai rata-rata sebesar 5,2489. Nilai minimum yang diperoleh yaitu $(-7,29)$ dan nilai tertinggi sebesar 55,00.

Variabel X2 merupakan leverage yang diproksikan dengan Debt to Equity Ratio (DER) menunjukan nilai rata-rata sebesar 11,63. Nilai ini menunjukkan bahwa rata-rata perusahaan memiliki hutang $11,63 \%$ dari modal yang dimiliki perusahaan. Nilai minimum yang diperoleh yaitu 0,00 dan nilai maksimum yaitu sebesar 123,00.

Variabel X3 ini merupakan kinerja lingkungan yang diukur dengan keberhasilan perusahaan memperoleh sertifikat sistem manajemen lingkungan ISO 
14001. Variabel X3 ini merupakan variabel dummy yang diukur melalui pemberian nilai 1 jika perusahaan memiliki sertifikat ISO14001 dan perusahaan akan diberikan nilai 0 jika tidak memiliki sertifikat ISO 14001. Hasil pengukuran menunjukkan nilai rata-rata sebesar 0,4667 atau $47 \%$. Nilai rata-rata variabel kinerja lingkungan yang diperoleh sebesar 0,37 atau $37 \%$. Nilai minimum untuk variabel ini adalah 0 dan nilai maksimumnya adalah 1 .

Variabel X4 dalam penelitian ini adalah diversifikasi gender dan juga merupakan variabel dummy. Perusahaan akan diberikan nilai 1 jika perusahaan memiliki anggota dewan direksi dan atau dewan komisaris yang berjenis kelamin perempuan. Sedangkan jika tidak ada anggota dewan komisaris atau dewan direksi yang berjenis kelamin perempuan, maka akan diberikan nilai 0 . Nilai rata-rata diversifikasi gender yang diperoleh sebesar 0,37 atau $37 \%$. Nilai minimum untuk variabel ini adalah 0 dan nilai maksimumnya adalah 1 .

\section{Hasil Uji Normalitas}

Hasil uji normalitas dalam program Eviews menunjukkan nilai probability JarqueBera sebesar 0,3309 dimana nilai ini berarti bahwa probability yang diperoleh lebih besar dari 0,05 sehingga dapat disimpulkan bahwa data telah terdistribusi secara normal.

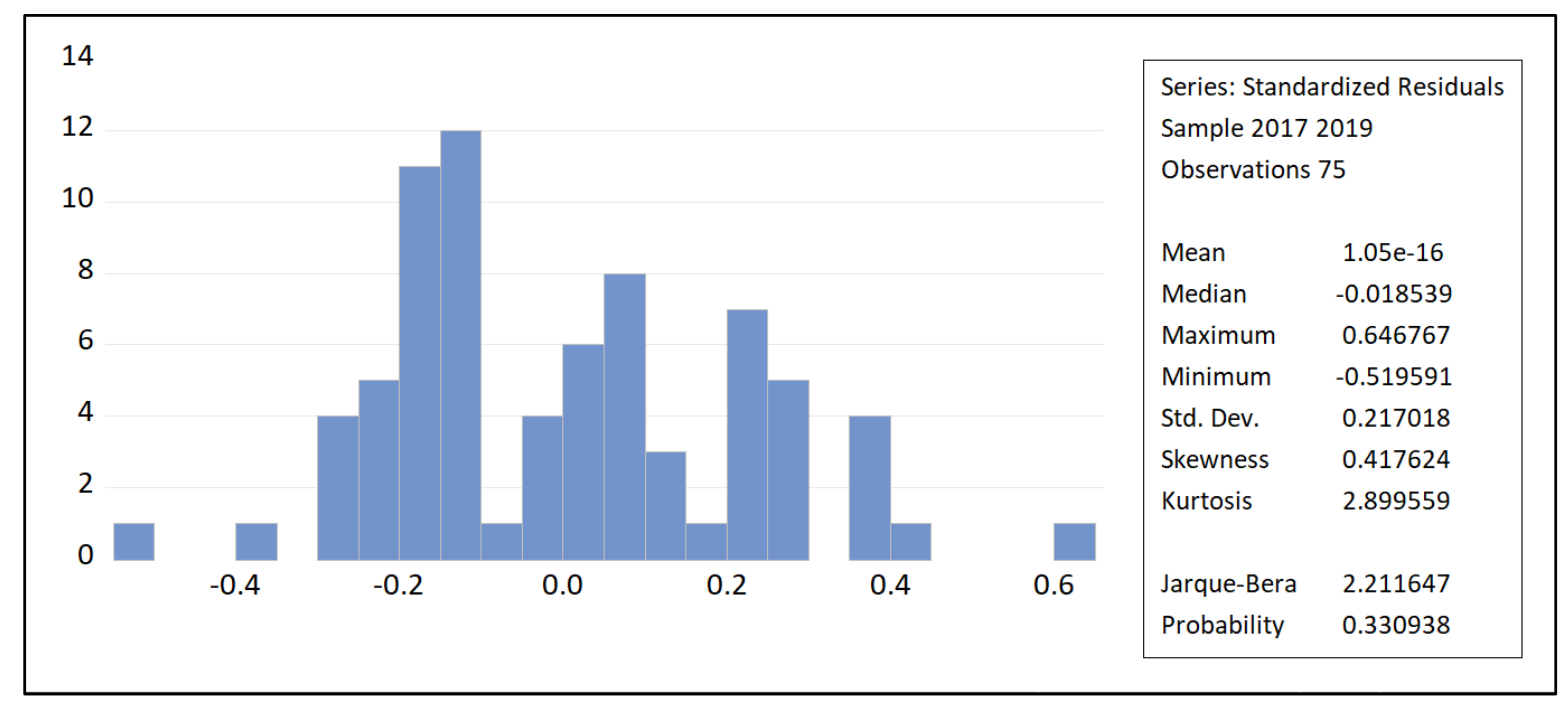

Gambar 1. Uji Normalitas Data

\section{Hasil Uji Multikolinieritas}

Tabel 3. Uji Multikolinieritas

\begin{tabular}{crrrr} 
& X1 & \multicolumn{1}{c}{ X2 } & \multicolumn{1}{c}{ X3 } & X4 \\
\hline \hline X1 & 1.000000 & 0.598823 & -0.023223 & 0.244126 \\
X2 & 0.598823 & 1.000000 & -0.210657 & 0.207586 \\
X3 & -0.023223 & -0.210657 & 1.000000 & 0.162080 \\
X4 & 0.244126 & 0.207586 & 0.162080 & 1.000000
\end{tabular}


https://akuntansi.pnp.ac.id/jam

Berdasarkan hasil uji multikolinieritas dalam tabel di atas dapat diketahui bahwa nilai seluruh variabel independennya tidak ada yang lebih besar dari 0,8 atau dengan kata lain nilainya kurang dari 0,8 sehingga dapat disimpulkan bahwa tidak terjadi masalah multikolinieritas.

\section{Hasil Uji Heteroskedastisitas}

Tabel 4. Uji Heteroskedastisitas

Dependent Variable: RESABS

Method: Panel Least Squares

Date: 03/18/21 Time: $12: 13$

Sample: 20172019

Periods included: 3

Cross-sections included: 25

Total panel (balanced) observations: 75

\begin{tabular}{crccc}
\hline \hline \multicolumn{1}{c}{ Variable } & Coefficient & Std. Error & t-Statistic & Prob. \\
\hline \hline C & 0.135129 & 0.022461 & 6.016117 & 0.0000 \\
X1 & 0.001483 & 0.001924 & 0.770602 & 0.4435 \\
X2 & 0.000170 & 0.000838 & 0.202412 & 0.8402 \\
X3 & 0.051688 & 0.029005 & 1.782036 & 0.0791 \\
X4 & 0.026554 & 0.029990 & 0.885448 & 0.3789 \\
\hline \hline Root MSE & 0.114973 & R-squared & & 0.085614 \\
Mean dependent var & 0.178920 & Adjusted R-squared & 0.033364 \\
S.D. dependent var & 0.121044 & S.E. of regression & 0.119008 \\
Akaike info criterion & -1.354914 & Sum squared resid & & 0.991401 \\
Schwarz criterion & -1.200415 & Log likelihood & & 55.80927 \\
Hannan-Quinn criter. & -1.293224 & F-statistic & & 1.638536 \\
Durbin-Watson stat & 0.531345 & Prob(F-statistic) & & 0.174264 \\
\hline \hline
\end{tabular}

Hasil uji tersebut menunjukkan bahwa variable X1 (Return on Asset) memiliki probability sebesar 0,4435, kemudian variabel X2 (Debt to Equity Ratio) memiliki probability sebesar 0,8402, variable X3 (Kinerja Lingkungan) memiliki probability sebesar 0.0791 dan variabel X4 (Diversifikasi Gender) memiliki probability sebesar 0,3789. Hasil tersebut menunjukkan bahwa seluruh variabel independen memiliki probabilita lebih dari 0,05 sehingga dapat disimpulkan bahwa tidak terjadi masalah heteroskedastisitas. 
Tabel 5. Uji Autokorelasi

Dependent Variable: $\mathrm{D}(\mathrm{Y})$

Method: Panel Least Squares

Date: 03/18/21 Time: 12:34

Sample (adjusted): 20192020

Periods included: 2

Cross-sections included: 25

Total panel (balanced) observations: 50

\begin{tabular}{crlrr}
\hline \hline \multicolumn{1}{c}{ Variable } & Coefficient & Std. Error & t-Statistic & Prob. \\
\hline \hline $\mathrm{C}$ & 0.022811 & 0.011638 & 1.960155 & 0.0562 \\
$\mathrm{D}(\mathrm{X} 1)$ & 0.002977 & 0.002152 & 1.383339 & 0.1734 \\
$\mathrm{D}(\mathrm{X} 2)$ & -0.002440 & 0.001721 & -1.417906 & 0.1631 \\
$\mathrm{D}(\mathrm{X} 3)$ & 0.008876 & 0.032696 & 0.271466 & 0.7873 \\
$\mathrm{D}(\mathrm{X} 4)$ & 0.028741 & 0.079428 & 0.361849 & 0.7192 \\
\hline \hline Root MSE & 0.074301 & R-squared & 0.047301 \\
Mean dependent var & 0.018200 & Adjusted R-squared & -0.037383 \\
S.D. dependent var & 0.076896 & S.E. of regression & 0.078320 \\
Akaike info criterion & -2.161381 & Sum squared resid & 0.276033 \\
Schwarz criterion & -1.970179 & Log likelihood & 59.03452 \\
Hannan-Quinn criter. & -2.088570 & F-statistic & 0.558562 \\
Durbin-Watson stat & 1.998677 & Prob(F-statistic) & 0.693854 \\
\hline \hline
\end{tabular}

Uji autokorelasi yang dilakukan menggunakan uji Durbit Watson (Uji DW). Hasil uji autokorelasi menunjukkan probabilita Durbin-Watson Statistic atau nilai DW sebesar 1,9987. Berdasarkan tabel Durbin Watson, diperoleh nilai dL sebesar 1,379 dan nilai dU sebesar 1,7214. Selain itu, diperoleh hasil 4 -dL yaitu sebesar 3,6221 dan 4-dU sebesar 2,2786. Jadi, dapat dilihat bahwa nilai DW yang diperoleh dalam tabel di atas berada di antara nilai dU dan $4-\mathrm{dU}$ atau $\mathrm{dU}<\mathrm{DW}<4-\mathrm{dU}$ $(1,7214<1,9987<2,2786)$ sehingga dapat disimpulkan bahwa tidak terjadi masalah autokorelasi dalam model regresi yang digunakan.

\section{Hasil Uji Kelayakan Model Hasil Uji Chow}

Tabel 6. Uji Chow

Redundant Fixed Effects Tests

Equation: Untitled

Test cross-section fixed effects

\begin{tabular}{|c|c|c|c|}
\hline Effects Test & Statistic & d.f. & Prob. \\
\hline Cross-section F & 30.747404 & $(24,46)$ & 0.0000 \\
\hline Cross-section Chi-square & 212.676611 & 24 & 0.0000 \\
\hline
\end{tabular}

Cross-section fixed effects test equation: 
https://akuntansi.pnp.ac.id/jam

e-ISSN 2657-1080, p-ISSN 1858-3687

Dependent Variable: $Y$

Method: Panel Least Squares

Date: 03/18/21 Time: 11:39

Sample: 20172019

Periods included: 3

Cross-sections included: 25

Total panel (balanced) observations: 75

\begin{tabular}{crrrr}
\hline \hline \multicolumn{1}{c}{ Variable } & Coefficient & Std. Error & t-Statistic & Prob. \\
\hline \hline C & 0.350878 & 0.042113 & 8.331749 & 0.0000 \\
X1 & 0.005111 & 0.003607 & 1.416937 & 0.1609 \\
X2 & -0.002390 & 0.001572 & -1.520537 & 0.1329 \\
X3 & 0.261142 & 0.054383 & 4.801945 & 0.0000 \\
X4 & -0.052974 & 0.056229 & -0.942123 & 0.3494 \\
\hline \hline Root MSE & 0.215566 & R-squared & & 0.310581 \\
Mean dependent var & 0.452000 & Adjusted R-squared & 0.271185 \\
S.D. dependent var & 0.261369 & S.E. of regression & & 0.223132 \\
Akaike info criterion & -0.097766 & Sum squared resid & 3.485153 \\
Schwarz criterion & 0.056733 & Log likelihood & & 8.666216 \\
Hannan-Quinn criter. & -0.036076 & F-statistic & & 7.883677 \\
Durbin-Watson stat & 0.285906 & Prob(F-statistic) & & 0.000026 \\
\hline \hline
\end{tabular}

Hasil uji chow seperti dalam tabel di atas menunjukkan bahwa nilai probability $\mathrm{F}<0.05$ sehingga model yang dipilih adalah model fixed effect.

\section{Hasil Uji Hausman}

Tabel 7. Uji Hausman

Correlated Random Effects - Hausman Test

Equation: Untitled

Test cross-section random effects

\begin{tabular}{lrrr}
\hline \hline Test Summary & Chi-Sq. Statistic & Chi-Sq. d.f. & Prob. \\
\hline \hline Cross-section random & 7.646219 & 4 & 0.1054 \\
\hline \hline
\end{tabular}

Cross-section random effects test comparisons:

\begin{tabular}{crrrr} 
Variable & Fixed & Random & Var(Diff.) & Prob. \\
\hline \hline X1 & 0.002086 & 0.003284 & 0.000001 & 0.2770 \\
X2 & -0.001970 & -0.002867 & 0.000001 & 0.3735 \\
X3 & 0.019480 & 0.057622 & 0.000238 & 0.0134 \\
X4 & -0.000394 & -0.003197 & 0.002826 & 0.9579 \\
\hline \hline
\end{tabular}

Cross-section random effects test equation:

Dependent Variable: $Y$

Method: Panel Least Squares 
https://akuntansi.pnp.ac.id/jam

e-ISSN 2657-1080, p-ISSN 1858-3687

Date: 03/18/21 Time: 11:40

Sample: 20172019

Periods included: 3

Cross-sections included: 25

Total panel (balanced) observations: 75

\begin{tabular}{crrrr}
\hline \hline Variable & Coefficient & Std. Error & \multicolumn{1}{c}{ t-Statistic } & Prob. \\
\hline \hline C & 0.455018 & 0.037098 & 12.26518 & 0.0000 \\
X1 & 0.002086 & 0.002358 & 0.884611 & 0.3810 \\
X2 & -0.001970 & 0.001775 & -1.109655 & 0.2729 \\
X3 & 0.019480 & 0.038109 & 0.511182 & 0.6117 \\
X4 & -0.000394 & 0.081670 & -0.004827 & 0.9962 \\
\hline \hline \multicolumn{6}{c}{} \\
\hline \hline
\end{tabular}

Cross-section fixed (dummy variables)

\begin{tabular}{lrll}
\hline \hline Root MSE & 0.052218 & R-squared & 0.959546 \\
Mean dependent var & 0.452000 & Adjusted R-squared & 0.934922 \\
S.D. dependent var & 0.261369 & S.E. of regression & 0.066676 \\
Akaike info criterion & -2.293454 & Sum squared resid & 0.204502 \\
Schwarz criterion & -1.397359 & Log likelihood & 115.0045 \\
Hannan-Quinn criter. & -1.935653 & F-statistic & 38.96780 \\
Durbin-Watson stat & 2.160945 & Prob(F-statistic) & 0.000000 \\
\hline
\end{tabular}

Dalam tabel hasil Uji Hausman di atas dapat dilihat bahwa probability chi square yang diperoleh adalah sebesar 0,1054 atau dengan kata lain nilai chi square $>0.05$ yang artinya Ho diterima sehingga model yang dipilih adalah model random effect.

\section{Hasil Uji Lagrange Multiplier (LM)}

Tabel 8. Uji LM

Lagrange Multiplier Tests for Random Effects

Null hypotheses: No effects

Alternative hypotheses: Two-sided (Breusch-Pagan) and one-sided

(all others) alternatives

\begin{tabular}{lccc}
\hline \hline & & Test Hypothesis & \\
& Cross-section & Time & Both \\
\hline \hline Breusch-Pagan & $\begin{array}{c}51.16339 \\
(0.0000)\end{array}$ & $\begin{array}{l}1.315658 \\
(0.2514)\end{array}$ & $\begin{array}{l}52.47905 \\
(0.0000)\end{array}$ \\
Honda & 7.152859 & -1.147021 & 4.246769 \\
& $(0.0000)$ & $(0.8743)$ & $(0.0000)$ \\
King-Wu & 7.152859 & -1.147021 & 0.881824 \\
& $(0.0000)$ & $(0.8743)$ & $(0.1889)$
\end{tabular}




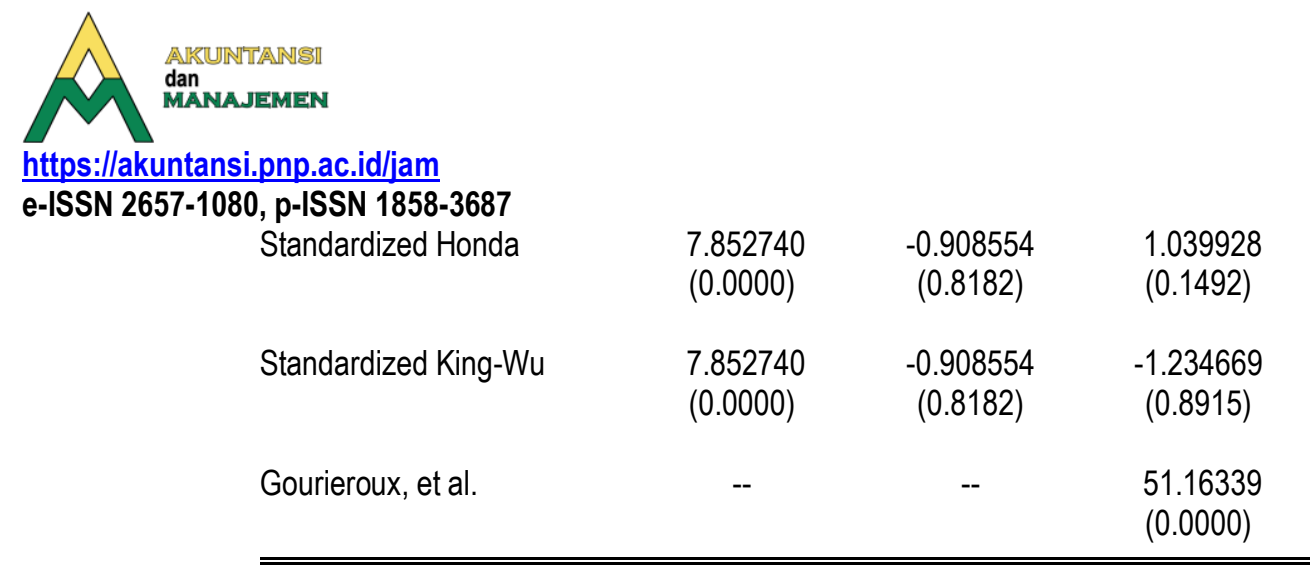

Berdasarkan hasil uji chow dan uji Hausman yang telah dilakukan, model yang tepat masih memiliki perbedaan sehingga harus dilakukan Uji Lagrange Multiplier (Uji LM) untuk menentukan model Random Effect atau Common Effect yang lebih tepat. Hasil Uji LM Breusch pagan dalam tabel di atas menunjukkan nilai probability chi square yang lebih kecil dari 0,05 sehingga Ho diterima yaitu model yang dipilih adalah model Common Effect. Persamaan regresi berdasarkan model Common Effect adalah seperti berikut:

Tabel 9. Model Common Effect

Dependent Variable: $Y$

Method: Panel Least Squares

Date: 03/18/21 Time: 11:35

Sample: 20172019

Periods included: 3

Cross-sections included: 25

Total panel (balanced) observations: 75

\begin{tabular}{crrrr}
\hline \hline \multicolumn{1}{c}{ Variable } & Coefficient & \multicolumn{1}{c}{ Std. Error } & t-Statistic & Prob. \\
\hline \hline C & 0.350878 & 0.042113 & 8.331749 & 0.0000 \\
X1 & 0.005111 & 0.003607 & 1.416937 & 0.1609 \\
X2 & -0.002390 & 0.001572 & -1.520537 & 0.1329 \\
X3 & 0.261142 & 0.054383 & 4.801945 & 0.0000 \\
X4 & -0.052974 & 0.056229 & -0.942123 & 0.3494 \\
\hline \hline Root MSE & 0.215566 & R-squared & & 0.310581 \\
Mean dependent var & 0.452000 & Adjusted R-squared & 0.271185 \\
S.D. dependent var & 0.261369 & S.E. of regression & & 0.223132 \\
Akaike info criterion & -0.097766 & Sum squared resid & & 3.485153 \\
Schwarz criterion & 0.056733 & Log likelihood & & 8.666216 \\
Hannan-Quinn criter. & -0.036076 & F-statistic & & 7.883677 \\
Durbin-Watson stat & 0.285906 & Prob(F-statistic) & & 0.000026 \\
\hline \hline
\end{tabular}

Berdasarkan hasil regresi di atas diperoleh persamaan :

$$
\mathrm{KPL}=0,3509+0,0051 \mathrm{ROA}-0,0023 \mathrm{DER}+0,2611 \mathrm{KL}-0.0530 \mathrm{DG}+\mathrm{e}
$$

\section{Hasil Uji Simultan (Uji F)}

Berdasarkan persamaan regresi yang diperoleh dapat diketahui bahwa nilai probability $\mathrm{F}$ statistik sebesar 0,000 atau $\mathrm{F}$ Statistic < 0,05 sehingga dapat disimpulkan bahwa variabel $\mathrm{X} 1, \mathrm{X} 2, \mathrm{X} 3$ dan $\mathrm{X} 4$ secara serentak berpengaruh 
https://akuntansi.pnp.ac.id/jam

terhadap variabel Y. Dengan kata lain, variable Return on Asset (ROA), Debt to Equity Ratio (DER), Sertifikasi Lingkungan dan Diversifikasi Gender secara bersama-sama berpengaruh terhadap variabel Kualitas Pengungkapan Lingkungan.

\section{Hasil Uji Parsial (Uji t)}

Berdasarkan hasil regresi yang diperoleh diketahui bahwa nilai probability masingmasing variabel independen seperti berikut:

- Variabel X1 yang diproksikan dengan Return on Asset (ROA) memiliki nilai probability sebesar 0,1609 yang artinya lebih besar dari 0,05 sehingga dapat disimpulkan bahwa variable $R O A$ tidak berpengaruh terhadap variabel kualitas pengungkapan lingkungan.

- Variabel X2 yang diproksikan dengan Debt to Equity Ratio (DER) memiliki nilai probability sebesar 0,1329 yang artinya probability tersebut lebih besar dari 0,05 sehingga dapat disimpulkan bahwa variabel DER tidak berpengaruh terhadap variabel kualitas pengungkapan lingkungan.

- Variabel X3 yang diproksikan dengan Kinerja Lingkungan memiliki nilai probability sebesar 0,0000 yang artinya probability yang diperoleh lebih kecil dari 0,05 sehingga dapat disimpulkan bahwa variabel kinerja lingkungan memiliki pengaruh terhadap variabel kualitas pengungkapan lingkungan.

- Variabel X4 yang diproksikan dengan Diversifikasi Gender memiliki nilai probability sebesar 0,3494 yang artinya probability tersebut lebih besar dari 0,05 sehingga dapat disimpulkan bahwa variabel diversitas gender tidak berpengaruh terhadap variabel kualitas pengungkapan lingkungan.

\section{Pengaruh Profitabilitas Terhadap Kualitas Pengungkapan Lingkungan}

Hasil penelitian menunjukkan bahwa profitabilitas tidak berpengaruh terhadap kualitas pengungkapan lingkungan. Hal ini menjelaskan bahwa semakin tinggi profitabilitas perusahaan ternyata tidak selalu memotivasi perusahaan untuk membuat pengungkapan lingkungan yang lebih baik. Data dalam penelitian ini menunjukkan bahwa beberapa perusahaan yang tingkat profitabilitasnya tinggi, mengungkapkan informasi lingkungan secara lebih lengkap sehingga kualitas pengungkapan lingkungannya tinggi, namun sebagian perusahaan yang tingkat profitabilitasnya rendah juga ada yang memiliki kualitas pengungkapan lingkungan yang tinggi. Oleh sebab itu, hasil penelitian ini belum dapat membuktikan bahwa profitabilitas dapat berpengaruh terhadap kualitas pengungkapan lingkungan.

Hasil penelitian ini sejalan dengan hasil penelitian [26] yang memperoleh hasil bahwa profitabilitas tidak berpengaruh terhadap pengungkapan lingkungan yang dibuat oleh perusahaan. Selain itu, penelitian [11] juga memperoleh hasil yang sama dimana profitabilitas tidak berpengaruh terhadap pengungkapan lingkungan yang dibuat oleh perusahaan. Begitu juga dengan hasil penelitian [16] yang menjelaskan bahwa hasil yang tidak berpengaruh kemungkinan terjadi karena para direktur merasa lebih optimis jika mengungkapkan informasi mengenai keuangan perusahaan dibandingkan mengungkapkan informasi yang masih bersifat voluntary seperti informasi tanggung jawab terhadap lingkungan. 
https://akuntansi.pnp.ac.id/jam

Pengaruh Leverage Terhadap Kualitas Pengungkapan Lingkungan

Hasil penelitian menunjukkan bahwa variabel leverage tidak memiliki pengaruh terhadap kualitas pengungkapan lingkungan perusahaan pertambangan yang menjadi sampel penelitian. Leverage dalam penelitian ini diproksikan dengan Debt to Equity Ratio (DER) yaitu rasio yang mengukur tingkat pengunaan hutang terhadap total shareholder equity yang dimiliki perusahaan [5]. Hasil ini didukung oleh penelitian [21] yang memperoleh hasil bahwa leverage tidak memiliki pengaruh terhadap pengungkapan lingkungan. Selanjutnya dijelaskan bahwa hasil yang tidak berpengaruh ini disebabkan karena perusahaan yang memiliki tingkat leverage yang tinggi cenderung memilih untuk mengungkapkan lebih banyak informasi mengenai pendapatannya dengan tujuan untuk lebih meyakinkan kreditor dibandingkan mengungkapkan informasi mengenai tanggung jawab perusahaan terhadap masyarakat.

\section{Pengaruh Kinerja Lingkungan Terhadap Kualitas Pengungkapan Lingkungan}

Hasil regresi menunjukkan bahwa kinerja lingkungan memiliki pengaruh terhadap kualitas pengungkapan lingkungan perusahaan pertambangan yang menjadi sampel dalam penelitian ini. Hasil penelitian ini didukung oleh [2] yang memperoleh hasil bahwa kinerja lingkungan memiliki pengaruh yang positif dan signifikan terhadap pengungkapan tanggung jawab sosial dan lingkungan. Sejalan dengan hasil ini, penelitian [24] juga menyebutkan bahwa kinerja lingkungan tidak berpengaruh terhadap pengungkapan CSR perusahaan dimana hasil ini menunjukkan bahwa perusahaan tidak memperhatikan kinerja lingkungan lingkungan dalam mengungkapkan tanggung jawab sosialnya sehingga bisa saja perusahaan yang tidak memiliki sertifikasi lingkungan justru mengungkapkan tanggung jawab sosialnya secara lebih luas. Hal tersebut dikarenakan belum ada standardisasi yang mengatur masalah pengungkapan tanggung jawab sosial perusahaan pada website perusahaan.

\section{Pengaruh Diverifikasi Gender Terhadap Kualitas Pengungkapan Lingkungan}

Hasil penelitian menunjukkan bahwa variabel diversivitas gender tidak berpengaruh terhadap kualitas pengungkapan lingkungan. Hal ini menunjukkan bahwa dengan keberadaan wanita dalam jajaran direksi ataupun komisaris yang merupakan posisi berpengaruh ternyata tidak membuat kualitas pengungkapan tanggung jawab perusahaan terhadap lingkungan menjadi lebih tinggi. Sejalan dengan hasil penelitian ini, [3] juga memperoleh hasil bahwa keberadaan peran wanita dalam jajaran direksi tidak berpengaruh terhadap pengungkapan lingkungan yang dibuat perusahaan karena hal tersebut juga tergantung pada budaya yang ada dalam perusahaan. Namun, hasil ini bertentangan dengan hasil penelitian [6] yang memperoleh hasil bahwa keberadaan wanita dalam jajaran dewan berpengaruh positif terhadap pengungkapan lingkungan perusahaan. 


\section{Kesimpulan}

Berdasarkan hasil dan pembahasan tersebut dapat disimpulkan profitabilitas tidak memiliki pengaruh terhadap kualitas pengungkapan lingkungan. Hal ini menjelaskan bahwa perusahaan yang memiliki kinerja keuangan yang tinggi tidak memotivasi perusahaan untuk mengungkapkan tanggung jawab terhadap lingkungan secara lebih luas juga. Demikian halnya dengan leverage juga tidak memiliki pengaruh terhadap kualitas pengungkapan lingkungan. Perusahaan dengan tingkat leverage yang tinggi cenderung lebih banyak mengungkapkan informasi keuangan dibandingkan informasi mengenai tanggung jawab sosial dan lingkungan. Dalam penelitian ini juga belum dapat memperoleh hasil bahwa diversifikasi gender berpengaruh terhadap kualitas pengungkapan lingkungan yang dibuat oleh perusahaan. Sementara variabel kinerja lingkungan memiliki pengaruh terhadap kualitas pengungkapan lingkungan. Hal ini menjelaskan bahwa perusahaan yang memiliki sertifikasi lingkungan IS014001 dalam penelitian ini mengungkapkan informasi lingkungan secara lebih luas dalam laporan tahunan perusahaan.

\section{Saran}

Berdasarkan hasil penelitian dan kesimpulan di atas, saran yang dapat diberikan yaitu bagi peneliti selanjutnya disarankan untuk meneliti variabel-variabel lain yang tidak digunakan dalam penelitian ini dengan waktu pengamatan yang lebih luas dan objek yang lebih banyak. Kemudian, untuk perusahaan seharusnya membuat pengungkapan informasi lingkungan secara lengkap sebagai bentuk tanggung jawab perusahaan terhadap lingkungan supaya mendapat kesan yang positif di hadapan para stakeholders yang pada akhirnya dapat memberikan dampak positif juga bagi kelangsungan perusahaan.

\section{REFERENSI}

[1] Aghdam, S. A. (2015). Determinants of Voluntary Environmental Disclosure : The Case of Iran. $4(6), 343-349$.

[2] Agung, A., \& Bawono, K. (2015). PENGARUH UKURAN PERUSAHAAN, LEVERAGE, PROFITABILITAS, CAKUPAN OPERASIONAL PERUSAHAAN, DAN SERTIFIKASI ISO 14001 TERHADAP PENGUNGKAPAN CORPORATE SOCIAL RESPONSIBILITY (Studi pada Perusahaan Manufaktur yang Terdaftar di BEI Tahun 2012-2013). Diponegoro Journal of Accounting , 4(3), 1-12.

[3] Alazzani, A., Hassanein, A., \& Aljanadi, Y. (2017). Impact of gender diversity on social and environmental performance: evidence from Malaysia. Corporate Governance (Bingley), 17(2), 266-283. https://doi.org/10.1108/CG-12-2015-0161

[4] Albertus, F., \& Zalukhu, Y. (2019). Dampak Dan Pengaruh Pertambangan Batubara 
Terhadap Masyarakat Dan Lingkungan Di Kalimantan Timur. Jurnal LEGALITAS, 4(1), 42-56.

http://ejurnal.untagsmd.ac.id/index.php/LG/article/download/4421/4279

[5] Armereo dan Pipit, C. (2019). Akuntansi dan Manajemen Vol.14, No.2, 201980 Akuntansi dan Manajemen. 14(2), 80-94.

[6] Baalouch, F., Ayadi, S. D., \& Hussainey, K. (2019). A study of the determinants of environmental disclosure quality: evidence from French listed companies. In Journal of Management and Governance (Vol. 23, Issue 4). Springer US. https://doi.org/10.1007/s10997-019-09474-0

[7] Budiasni, N. W. N., \& Darma, G. S. (2016). Penerapan Corporate Social Responsibility pada Lembaga Keuangan Berbasis Kearifan Lokal. Jurnal Manajemen Dan Bisnis, 15(2), 151-174.

[8] Campbell, D. (2004). A longitudinal and cross-sectional analysis of environmental disclosure in UK companies - A research note. British Accounting Review, 36(1), 107-117. https://doi.org/10.1016/j.bar.2003.09.001

[9] Chebbi, K. (2021). Women on the Board and Environmental Sustainability Reporting : Evidence from France. December 2020.

[10] Deegan, C. (2002). Introduction: The legitimising effect of social and environmental disclosures - a theoretical foundation. Accounting, Auditing \& Accountability Journal, 15(3), 282-311. https://doi.org/10.1108/09513570210435852

[11] Deswanto, R. B. \& S. V. S. (2018). The associations between environmental disclosures with financial performance, environmental performance, and firm value. Emerald. https://www.emerald.com/insight/content/doi/10.1108/SRJ-012017-0005/full/html

[12] Eljayash, K. M., James, K., \& Kong, E. (2012). The Quantity and Quality of Environmental Disclosure in Annual Report of National Oil and Gas Companies in Middle East and North Africa. International Journal of Economics and Finance, 4(10), 201-218. https://doi.org/10.5539/ijef.v4n10p201

[13] Fachlevi, T. A., Putri, E. I. K., \& Simanjuntak, S. M. H. (2016). Dampak Dan Evaluasi Kebijakan Pertambangan Batubara Di Kecamatan Mereubo. RISALAH KEBIJAKAN PERTANIAN DAN LINGKUNGAN: Rumusan Kajian Strategis Bidang Pertanian Dan Lingkungan, 2(2), 170. https://doi.org/10.20957/jkebijakan.v2i2.10989

[14] Fadjrih Asyik, N. (2016). PERSPEKTIF AGENCY THEORY: PENGARUH INFORMASI ASIMETRI TERHADAP MANAJEMEN LABA (Menggunakan Pendekatan Agency Framework). EKUITAS (Jurnal Ekonomi Dan Keuangan), 4(1), 29. https://doi.org/10.24034/j25485024.y2000.v4.i1.1898

[15] Farida, D. N. (2019). Pengaruh Diversitas Gender Terhadap Pengungkapan Sustainability Development Goals. Jurnal Akuntansi Indonesia, 8(2), 89. https://doi.org/10.30659/jai.8.2.89-107 
https://akuntansi.pnp.ac.id/jam

[16] Hadiprajitno, B. \& A. P. F. (2015). The Effects of Corporate Governance Structure on Firms' Characteristic Towards Environmental Disclosure. Productivity Review, 24(1), 1-11. https://doi.org/10.15843/kpapr.24.1.201003.205

[17] Hadya, R., \& Susanto, R. (2018). Model Hubungan Antara Keberagaman Gender, Pendidikan Dan Nationality Dewan Komisaris Terhadap Pengungkapan Corporate $\begin{array}{llll}\text { Social Responsibility. Jurnal Benefita, } & 149 .\end{array}$ https://doi.org/10.22216/jbe.v3i2.3432

[18] ISO 14001. (2015). Introduction to ISO 14001:2015. Introduction to ISO, 1-13. www.iso.org/iso/introduction_to_iso_14001.pdf

[19] Juhmani, O. (2014). Determinants of corporate social and environmental disclosure on websites: the case of Bahrain. Universal Journal of Accounting and Finance, 2(4), 77-87. https://doi.org/10.13189/ujaf.2014.020402

[20] Listiyani, N. (2017). Dampak Pertambangan Terhadap Lingkungan Hidup di Kalimantan Selatan dan Implikasinya Bagi Hak-Hak Warga Negara. IX(April), 6786.

[21] Maulia, D., \& Yanto, H. (2020). The Determinants of Environmental Disclosure in Companies in Indonesia. 12(1), 178-188.

[22] Rahmadani, Ananto, R. P., \& Andriani, W. (2019). TERHADAP STRUKTUR MODAL ( Studi pada Perusahaan Property dan Realestate yang terdaftar di BEI tahun 20132017). 14(1), 82-103.

[23] Rahmatillah, S. (2018). Syarifah Rahmatillah \& Tasbi Husen: Penyalahgunaan Pengelolaan... P a g e / 149. VII(1), 149-171.

[24] Ramadhan, H. dan H. A. S. (2018). Pengaruh Karakteristik Perusahaan, Media Exposure dan Sertifikasi Lingkungan Terhadap Corporate Social Responsibility Disclosure. Prosiding Forum Manajemen Indonesia Ke-10.

[25] Rezaee, Z. (2015). Business Sustainability: Performance, Compliance, Accountability and Integrated Reporting. Greenleaf Publishing Limited. https://books.google.co.id/books?hl=id\&lr=\&id=hqo0DwAAQBAJ\&oi=fnd\&pg=P T12\&dq=Business++Sustainability+:+Performance,+Compliance,+Accountability ++ and++Integrated++Reporting\&ots=lhaOCIDeuf\&sig=4MKqgM6MeRheljtzgKX0 eRQ7SJc\&redir_esc=y\#v=onepage \&q=Business $\mathrm{Su}$

[26] Shonhadji, N. (2018). $I \quad j \quad r \quad s \quad m . \quad 5(8), \quad 183-191$. https://doi.org/10.5281/zenodo.1405443

[27] Sulaiman, M., Abdullah, N., \& Fatima, A. H. (2014). Determinants ef environmental reporting. International Journal of Economics, 22(1), 63-90.

[28] Ulum, I. (2017). Intellectual Capital: Model Pengukuran, Framework Pengungkapan \& Kinerja Organisasi. Universitas Muhammadiyah Malang. https://www.google.co.id/books/edition/INTELLECTUAL_CAPITAL/e25jDwAA QBAJ?hl=id\&gbpv=1\&dq=teori+legitimasi+adalah\&pg=PA42\&printsec=frontcov 
er

[29] Utomo, M. N. (2019). Ramah Lingkungan dan Nilai Perusahaan. Jakad Publishing. https://www.google.co.id/books/edition/Ramah_Lingkungan_dan_Nilai_Perusa haan/aJTZDwAAQBAJ?hl=id\&gbpv=1\&dq=.+Ramah++Lingkungan++dan++Nilai+ +Perusahaan.+Surabaya+:+Jakad++Publishing.\&pg=PP3\&printsec=frontcover

[30] Wati, L. N. (2019). Model Corporate Social Responsibility (CSR). Myria Publisher. https://www.google.co.id/books/edition/Model_Corporate_Social_Responsibilit y_CS/lKPHDwAAQBAJ?hl=id\&gbpv=1\&dq=.+Model++Corporate++Social++Respo nsibility+(CSR).+Jawa+Timur+:+Myria++Publisher.\&pg=PR2\&printsec=frontcov er 